\title{
Association between education and blood lipid levels as income increases over a decade: a cohort study
}

\author{
Macarena Lara* (iD and Hugo Amigo
}

\begin{abstract}
Background: Cardiovascular risk factors have increased along with economic development, but it is not clear if this tendency differs by education. The aim of this study was to analyze the effect of education on blood lipid levels while income increases over a decade in Chilean adults.

Methods: A cohort study was conducted from 3092 births in Limache Hospital between 1974 and 1978, of which 998 people were randomly selected in 2000 and 650 followed up in 2010. Using mediation analysis, the controlled direct effect (CDE) of education in 2000 on blood lipid levels in 2010: triglycerides (TG), total cholesterol (TC), LDL cholesterol (LDL) and HDL cholesterol (HDL) while setting the mediator, income, to "increased" between 2000 and 2010 was estimated. The results were expressed through the CDE and its 95\% confidence interval (Cl).

Results: Of the 650 adults, 24\% had low education ( $\leq 8$ years) and 60\% increased their income. The mediation analysis showed that, when setting income to "increased", women with low education had worse lipid profiles than women with high education: $\mathrm{TG}_{\mathrm{CDE}}=14(\mathrm{Cl}=-7 ; 34), \mathrm{TC}_{\mathrm{CDE}}=4(\mathrm{Cl}=-8 ; 15), \mathrm{LDL}_{\mathrm{CDE}}=1(\mathrm{Cl}=-8 ; 9), \mathrm{HDL}_{\mathrm{CDE}}=-3(\mathrm{Cl}=-7 ; 0)$, while men with low education had better lipid profiles than men with high education: $\mathrm{TG}_{\mathrm{CDE}}=-2(\mathrm{Cl}=-41 ; 38)$, $\mathrm{TC}_{\mathrm{CDE}}=-12(\mathrm{Cl}=-29 ; 5), \mathrm{LDL}_{\mathrm{CDE}}=-12(\mathrm{Cl}=-24 ; 1), \mathrm{HDL}_{\mathrm{CDE}}=1(\mathrm{Cl}=-5 ; 6)$.
\end{abstract}

Conclusion: Faced with a rise in income, there was a trend to associate low education with worse lipid profiles in women and better lipid profiles in men.

Keywords: Education, Income change, Blood lipids, Health inequalities, Gender, Mediation analysis

\section{Background}

Currently, cardiovascular diseases are the main cause of death in Chile and worldwide [1-3]. In 2015, the World Health Organization reported that 17.7 millions of people died from cardiovascular diseases (equivalent to $31 \%$ of the total deaths in the world) and were responsible for $27 \%$ of the deaths in Chile [1,3]. Projections indicate that the number of deaths due to cardiovascular diseases will increase to 23.3 million by 2030 [4].

Among the modifiable risk factors of cardiovascular diseases are smoking, obesity, sedentary lifestyle, hypertension, diabetes mellitus and dyslipidemia [5]. It has been observed that each of these factors has increased quickly in recent decades reaching high levels globally [6]. These

\footnotetext{
* Correspondence: macarena.lara.m@gmail.com

Department of Nutrition, University of Chile, Independencia 1027, 8380453 Santiago, Chile
}

(c) The Author(s). 2018 Open Access This article is distributed under the terms of the Creative Commons Attribution 4.0 International License (http://creativecommons.org/licenses/by/4.0/), which permits unrestricted use, distribution, and reproduction in any medium, provided you give appropriate credit to the original author(s) and the source, provide a link to the Creative Commons license, and indicate if changes were made. The Creative Commons Public Domain Dedication waiver (http://creativecommons.org/publicdomain/zero/1.0/) applies to the data made available in this article, unless otherwise stated.

trends are also present in Chile since, according to the last National Health Survey conducted between 2009 and 2010, $41 \%$ of Chilean adults smoke, $25 \%$ are obese, $89 \%$ are sedentary, $27 \%$ have hypertension, $9 \%$ diabetes and $39 \%$ high cholesterol [7].

It has been observed that the prevalence of cardiovascular risk factors has increased along with the economic improvements, especially in developing countries [2]. In Latin America, poverty has fallen significantly since 2000. The proportion of people living under poverty line in the region has been almost cut in half since 2000 to $23 \%$ in 2015 [8]. Chile has been one of Latin America's fastest-growing economies in recent decades, reducing the poverty rate from $20 \%$ in 2000 to $15 \%$ a decade later [9] and becoming one of the most economically stable countries in South America [10,11]. 
Parallel to this fast economic growth, cardiovascular risk factors rates increased in Chilean adults [7, 12]. Globalization, urbanization and industrialization have accompanied this economic transition, impacting population lifestyles and leading to higher rates of cardiovascular diseases [2,13]. Currently, Chilean adults are living in an obesogenic enviroment with high rates of sedentarism and unhealthy diets, high in sugar, fat and salt, which all contribute to cardiovascular diseases [14, 15].

In the last National Health Survey, most of the cardiovascular risk factors were more frequent at lower education level, showing a gradient toward improved health outcomes as education increases [7]. It has been reported that people with low education are more susceptible to acquiring less healthy eating patterns and lifestyles, and this could be accentuated when their income increases without an improvement in their education $[16,17]$.

Three mechanisms have been proposed to explain the relationship between education and health [17]. The first is that education increases knowledge and health behaviors directly $[18,19]$ which can be seen in studies that show an association between education and consumption of healthier food as well as increased physical activity [20, 21]. The second possible mechanism is that increased education can lead to better employment opportunities that allow people to live in better, less stressful environments with a higher availability of health food options and recreational areas $[22,23]$. The last mechanism is that higher education is associated with psychosocial factors such as a sense of control, social position and social support, that help to reduce barriers to change and maintain improvements in health behaviors [24-26].

Considering the economic improvements, it is still unclear whether there are differences in adults blood lipid levels by education status. This information could be useful to understand the mechanisms involved in the production of this type of health inequalities. Therefore, the objective of this study was to analyze the effect of education on blood lipid levels while considering the change in income between 2000 and 2010 in adults born between 1974 and 1978 in Limache Hospital, Chile.

\section{Methods}

\section{Study population and design}

A concurrent cohort study was undertaken in Limache and Olmué, which are adjoining towns located $108 \mathrm{~km}$ from Santiago, the capital of Chile. Both are considered semi-rural communities, and their main economic activity is agriculture and more recently tourism. In 2000, 998 adults were randomly selected from a sampling frame of 3092 newborns registered between 1974 and 1978 in Limache Hospital [27]. In 2010, 650 of them were followed-up.

\section{Collection of information}

Socio-demographic information was collected using a structured questionnaire that asked about age, years of education at baseline and per-capita income in 2000 and 2010. Salaries, pensions, social program benefits and dividends were all included as sources of income. Per-capita income was calculated from the monthly household income divided by the number of household members weighted by the OECD equivalence scale [28] and corrected for inflation during the study period [29]. Socioeconomic level in 2000 was described using a validated index that consisted of a two-dimensional social grade matrix that combined the educational level and occupation of the head of the household and categorized the socioeconomic level into five strata: high, middle-high, middle, middle-low and low [30]. As very few participants were observed in the highest two socioeconomic levels, they were merged into the middle group.

Weight and height in 2010 were measured to calculate body mass index (BMI). Bicipital, tricipital, subscapular and suprailiac skinfold thickness were measured using a Harpenden Caliper to compute skinfold thickness sum in 2010. All these measurements were taken by standardized and periodically monitored nutritionists, using as reference the protocol for anthropometric measures proposed by the World Health Organization [31].

Physical activity in 2010 was measured using the International Physical Activity Questionnaire (IPAQ), which has been translated and validated in different countries [32]. Energy intake in 2010 was estimated with a quantified food frequency questionnaire applied by nutritionists who collected information on food intake during the last 30 days of each participant by interview.

Measurements and blood specimens (with $12 \mathrm{~h}$ fasting) were obtained in a hospital or local health facility. Trained and supervised nurses measured blood lipid levels. Blood samples were processed at Limache Hospital and frozen for later laboratory analysis. Blood lipid levels were measured by enzymatic colorimetric method: tryglicerides (HUMAN Ref 10,724), total cholesterol (HUMAN Ref 10,028), HDL cholesterol (HUMAN Ref 10,084) and LDL cholesterol (HUMAN Ref 10,094). In adults with tryglicerides levels below $400 \mathrm{mg} / \mathrm{dL}$, LDL cholesterol level was calculated using the Friedewald formula [33].

Information about maternal education and family history of obesity and dyslipidemia was collected via questionnaire. Birth weight was collected from the official hospital register.

\section{Analysis}

Education was dichotomized into "low education" if the person had 8 or less years of education approved and "high education" if the person had more than 8 years approved. The income change was dichotomized into "increases" if 
income increased by $10 \%$ or more between 2000 and 2010 and "decreases" if not. The outcomes were continuous blood lipid levels in 2010 (triglycerides, total cholesterol, HDL and LDL cholesterol).

Mediation analysis was used [34] considering "education in 2000" as exposure, "income change between 2000 and $2010 "$ as the mediator and "blood lipid levels in 2010" as outcomes. This analysis is based on a causal mediation model and estimates the controlled direct effect (CDE). The CDE corresponds to the effect of exposure (education in 2000) on the outcome in 2010 when the mediator (income change between 2000 and 2010) is set to 1 (income increased). In other words, it is the effect of all paths from exposure to outcome that do not pass through the mediator.

Separate models for each outcome were fit for the total sample and by sex, the results were expressed through the $\mathrm{CDE}$ and $95 \%$ confidence intervals (CI) and prior to analysis it was tested whether there was interaction between exposure and a mediator, considering a $p$-value $<0.10$ to be significant. Confounding variables such as sex, age, birth weight, income at baseline, maternal education and family history of obesity and dyslipidemia were considered. Losses to follow up were quantified and the characteristics of the group that remained in the study were contrasted with the group that was lost to verify whether the losses to follow up were related to exposure and outcome which could introduce a selection bias [35]. Inverse probability of censoring weighting was used to solve this problem [35, 36]. Raw models and models adjusted for confounders and weighted by inverse probability of censoring to consider losses to follow up were presented.

\section{Results}

From 998 adults at baseline, 35\% were loss to follow up during the ten years of the study. Therefore, 650 participants were measured in both 2000 and 2010 .

Table 1 describes the characteristics of the cohort in 2000 and 2010. At baseline, the age of the sample ranged between 22 and 28 years, the mean of education level was below a high school degree and the monthly percapita income was 97 USD, 19\% higher in men than women $(p=0.005)$. Distribution of socioeconomic level was different by sex, the proportion of low socioeconomic level was almost the double in women than men. Nearly a quarter of the adults had low education and the difference in this proportion was not significant between women and men $(p=0.326)$. Between 2000 and 2010, $60 \%$ of the sample increased greater than $10 \%$ their percapita income.

In 2010, the blood lipid profiles were similar by sex with the exception of triglycerides, which were $29 \mathrm{mg} / \mathrm{dL}$ higher in men than women $(p<0.001)$. Men also had an $8 \%(p=0.027)$ higher prevalence of hyperglycemia and the proportion of men with high blood pressure was almost the double that in women $(p=0.004)$. On the other hand, women had $1 \mathrm{~kg} / \mathrm{m}^{2}$ higher BMI and $26 \mathrm{~mm}$ higher skinfold thickness sum than men $(p<0.004)$. Although women reported having a lower daily energy intake, their physical activity was much lower than men $(p<0.001)$. It is important to mention that $75 \%$ of the adults were overweight or obese at 35 years old. While overweight was more frequent in men obesity was more frequent in women (Table 1).

Table 2 shows the differences in blood lipid levels and other related variables by education in the total sample and separated by sex. Mean blood lipid levels tended to be worse in women and better in men with low education in comparison to their peers with high education. Also, women with low education had $2 \mathrm{~kg} / \mathrm{m}^{2}$ higher BMI and $8 \mathrm{~mm}$ higher skinfold thickness sum than women with high education, while men with low education had 2334 METs/week more and $14 \mathrm{~mm}$ less of skinfold thickness sum than men with high education.

Before the mediation analysis was performed, interaction between exposure (education in 2000) and mediator (income change between 2000 and 2010) was confirmed when the effect on HDL cholesterol $(p=0.052)$ was analyzed. It was also necessary to use inverse probability of censoring weighting to avoid selection bias after observing that more men, people with higher education and less obesity were lost.

Table 3 shows the results of the mediation analysis that measured the effect of education in 2000 on blood lipid levels in 2010 had income increased during the decade studied. Crude and adjusted models are presented weighted by the inverse probability of censoring. As mentioned previously, the results for each type of analysis were expressed as the $\mathrm{CDE}$ and its $\mathrm{CI}$ for the total sample and by sex (Table 3 ).

Models adjusted for confounders and weighted for loss to follow-up showed that setting income to "increased" between 2000 and 2010, women with low education had a non-significant trend toward worse lipids profiles than their peers with high education: $\mathrm{CDE}_{\mathrm{TG}}=14(\mathrm{CI}=-7$; 34), $\mathrm{CDE}_{\mathrm{CT}}=4(\mathrm{CI}=-8 ; 15), \mathrm{CDE}_{\mathrm{LDL}}=1(\mathrm{CI}=-8 ; 9)$, $\mathrm{CDE}_{\mathrm{HDL}}=-3(\mathrm{CI}=-7 ; 0)$. In contrast, men with low education had a non-significant trend toward better lipid profiles than men with high education: $\mathrm{CDE}_{\mathrm{TG}}=-2(\mathrm{CI}$ $=-41 ; 38), \mathrm{CDE}_{\mathrm{CT}}=-12(\mathrm{CI}=-29 ; 5), \mathrm{CDE}_{\mathrm{LDL}}=-12$ $(\mathrm{CI}=-24,1), \mathrm{CDE}_{\mathrm{HDL}}=1(\mathrm{CI}=-5,6)($ Table 3$)$.

\section{Discussion}

Faced with an increase in income between 2000 and 2010, women with low education had a trend toward worse lipid profiles while men with low education had a trend toward better lipid profiles, compared to their peers with high education. 
Table 1 Description of the cohort at baseline (2000) and follow-up (2010)

\begin{tabular}{|c|c|c|c|c|}
\hline & $\begin{array}{l}\text { Total } \\
(n=650)\end{array}$ & $\begin{array}{l}\text { Women } \\
(n=428)\end{array}$ & $\begin{array}{l}\text { Men } \\
(n=222)\end{array}$ & \\
\hline Characteristics in 2000 & Mean \pm SD & Mean \pm SD & Mean \pm SD & $p$ \\
\hline Age (years) & $25 \pm 2$ & $25 \pm 2$ & $25 \pm 2$ & 0.333 \\
\hline Education (years approved) & $11 \pm 3$ & $11 \pm 3$ & $11 \pm 3$ & 0.118 \\
\hline \multirow[t]{2}{*}{ Per-capita income (USD/month) } & $97 \pm 90$ & $89 \pm 82$ & $111 \pm 103$ & 0.005 \\
\hline & $\%$ & $\%$ & $\%$ & $p^{a}$ \\
\hline \multicolumn{5}{|l|}{ Socioeconomic level } \\
\hline low & 28 & 34 & 18 & $<0.001$ \\
\hline middle low & 38 & 29 & 57 & \\
\hline middle and high & 34 & 37 & 25 & \\
\hline Low Education ( $\leq 8$ years) & 24 & 23 & 26 & 0.326 \\
\hline Increased income (2000-2010) & 60 & 58 & 62 & 0.416 \\
\hline Characteristics in 2010 & Mean \pm SD & Mean \pm SD & Mean \pm SD & $p$ \\
\hline Triglycerides (mg/dL) & $133 \pm 73$ & $123 \pm 66$ & $152 \pm 81$ & $<0.001$ \\
\hline Total cholesterol (mg/dL) & $182 \pm 36$ & $182 \pm 36$ & $183 \pm 36$ & 0.871 \\
\hline LDL cholesterol (mg/dL) & $111 \pm 27$ & $112 \pm 27$ & $108 \pm 27$ & 0.075 \\
\hline HDL cholesterol (mg/dL) & $48 \pm 12$ & $47 \pm 12$ & $48 \pm 12$ & 0.458 \\
\hline Glycemia (mg/dL) & $93 \pm 18$ & $92 \pm 18$ & $95 \pm 17$ & 0.077 \\
\hline Systolic blood pressure (mm Hg) & $119 \pm 16$ & $116 \pm 15$ & $125 \pm 15$ & $<0.001$ \\
\hline Diastolic blood pressure (mm Hg) & $74 \pm 12$ & $73 \pm 11$ & $76 \pm 12$ & $<0.001$ \\
\hline $\mathrm{BMI}\left(\mathrm{kg} / \mathrm{m}^{2}\right)$ & $29 \pm 5$ & $29 \pm 5$ & $28 \pm 4$ & 0.003 \\
\hline Skinfold thickness sum (mm) & $76 \pm 27$ & $85 \pm 24$ & $59 \pm 22$ & $<0.001$ \\
\hline Physical activity (METs/week) & $3486 \pm 3920$ & $2536 \pm 2955$ & $5317 \pm 4809$ & $<0.001$ \\
\hline \multirow[t]{2}{*}{ Energy intake (Kcal/day) } & $2285 \pm 920$ & $1946 \pm 688$ & $2948 \pm 956$ & $<0.001$ \\
\hline & $\%$ & $\%$ & $\%$ & $p^{a}$ \\
\hline Triglycerides > 150 mg/dL & 33 & 28 & 43 & $<0.001$ \\
\hline Total cholesterol > 200 mg/dL & 28 & 27 & 31 & 0.286 \\
\hline LDL cholesterol > 130 mg/dL & 21 & 22 & 21 & 0.766 \\
\hline $\mathrm{HDL}$ cholesterol $<40 \mathrm{mg} / \mathrm{dL}$ & 28 & 28 & 27 & 0.737 \\
\hline Glycemia > 100 mg/dL & 21 & 18 & 26 & 0.027 \\
\hline Blood Pressure $\geq 140 / 90 \mathrm{mmHg}$ & 15 & 12 & 20 & 0.004 \\
\hline Nutritional status & & & & 0.022 \\
\hline normal & 25 & 24 & 28 & \\
\hline overweight & 41 & 39 & 45 & \\
\hline obesity & 34 & 37 & 26 & \\
\hline
\end{tabular}

Student t-test; ${ }^{\mathrm{a}} \mathrm{Chi}^{2}$ test

The mean of years of education in the adults studied was one year lower than the mean reported for the Chilean population between 22 and 28 years in 2000, and while the proportion of adults with primary degree or less was almost a quarter of the sample studied it was $18 \%$ nationally, according to the National Socioeconomic Characterization Survey conducted in 2000 [37].

The improvement in per-capita income was consistent with the economic growth in this period at the national level $[9,10]$. More than the half of the participants in this study increased their monthly per-capita income, which could be attributed to the change in the main economic activity in the place studied. While agriculture was most important in 2000, it was displaced by social community services, such as tourism, education, health, among others, which ranked first in 2009 [37, 38].

The mean of cardiometabolic and anthropometric parameters were similar to the national average of the 
Table 2 Differences in blood lipid levels and related variables by education level

\begin{tabular}{|c|c|c|c|c|c|c|c|c|c|}
\hline \multirow[t]{2}{*}{ Variables in 2010} & \multicolumn{3}{|l|}{ Total } & \multicolumn{3}{|l|}{ Women } & \multicolumn{3}{|l|}{ Men } \\
\hline & $\begin{array}{l}\text { Low } \\
\text { education }\end{array}$ & $\begin{array}{l}\text { High } \\
\text { education }\end{array}$ & $p$ & $\begin{array}{l}\text { Low } \\
\text { education }\end{array}$ & $\begin{array}{l}\text { High } \\
\text { education }\end{array}$ & $p$ & $\begin{array}{l}\text { Low } \\
\text { education }\end{array}$ & $\begin{array}{l}\text { High } \\
\text { education }\end{array}$ & $p$ \\
\hline Triglycerides (mg/dL) & $136 \pm 6$ & $132 \pm 3$ & 0.548 & $133 \pm 6$ & $120 \pm 4$ & 0.098 & $142 \pm 11$ & $156 \pm 6$ & 0.246 \\
\hline Total cholesterol (mg/dL) & $183 \pm 3$ & $182 \pm 2$ & 0.667 & $186 \pm 4$ & $181 \pm 2$ & 0.217 & $179 \pm 5$ & $184 \pm 3$ & 0.345 \\
\hline LDL cholesterol (mg/dL) & $110 \pm 2$ & $111 \pm 1$ & 0.745 & $114 \pm 3$ & $112 \pm 1$ & 0.423 & $104 \pm 3$ & $110 \pm 2$ & 0.133 \\
\hline HDL cholesterol (mg/dL) & $47 \pm 1$ & $48 \pm 1$ & 0.499 & $46 \pm 1$ & $48 \pm 1$ & 0.090 & $50 \pm 2$ & $48 \pm 1$ & 0.266 \\
\hline Physical activity (METs/week) & $4117 \pm 4428$ & $3288 \pm 3730$ & 0.021 & $2369 \pm 2773$ & $2584 \pm 3009$ & 0.529 & $7041 \pm 5110$ & $4707 \pm 4560$ & 0.001 \\
\hline Energy intake (Kcal/day) & $2321 \pm 1006$ & $2273 \pm 893$ & 0.578 & $1830 \pm 631$ & $1980 \pm 701$ & 0.062 & $3154 \pm 978$ & $2876 \pm 941$ & 0.061 \\
\hline $\mathrm{BMI}\left(\mathrm{kg} / \mathrm{m}^{2}\right)$ & $29 \pm 6$ & $28 \pm 5$ & 0.086 & $30 \pm 6$ & $28 \pm 5$ & 0.002 & $27 \pm 5$ & $28 \pm 4$ & 0.119 \\
\hline Skinfold thickness sum (mm) & $75 \pm 32$ & $76 \pm 25$ & 0.523 & $91 \pm 26$ & $83 \pm 24$ & 0.007 & $48 \pm 22$ & $62 \pm 21$ & $<0.001$ \\
\hline
\end{tabular}

Values expressed as mean \pm standard deviation; Student t-test; Low education: $\leq 8$ years, High education $>8$ years

same age group [39]. Men had a higher frequency of elevated tryglicerides, hyperglycemia and hypertension than women, as has been previously reported for young adults $[40,41]$. The fact that three quarters of the cohort reported being overweight or obese, and that this prevalence is similar to the Chilean population, demonstrates that the overweight and obesity epidemic is an important public health issue in Chile [7] as is the case with most countries internationally [42].

Women with low education had higher BMI and skinfold thickness sum than women with high education. This is consistent with other studies that have observed higher anthropometric measurements in less educated women as a consequence of genetic and environmental factors interacting [43-46]. Women did not have difference in physical activity by education and this could be explained because most women sampled had sedentary occupations regardless their education status. Instead men with low education had higher physical activity and lower skinfold thickness sum, possibly because their occupation required more physical work and this could have reduced body fat and could have improved their blood lipid levels. There was no observed difference in BMI by education in men and it could be possibly because it is an anthropometric index that which is not able to differentiate lean from fat mass. The daily energy intake in both women and men was slightly higher than the reported by the National Food Survey conducted in Chile in 2009-2010 [47]. The lack of difference in daily energy intake by education could be explained by the recall and social desirability bias associated with the instrument [48-50].

Low education was associated with worse lipid profiles in women and better lipid profiles in men (both without statistical significance, but with a tendency toward these results). The lack of statistical significance could be interpreted in two ways: there is possibly a significant effect, but it would be necessary to increase the sample size or work with a more heterogeneous sample because socioeconomic homogeneity of the sample could be masking relevant effects of education on blood lipid levels and in a more heterogeneous scenario they could be visible. The other interpretation is that education is really not directly influencing the current blood lipid levels and other variables may have more to do with them. Another possibility is that the effect of education on blood lipid levels is small because the biological variability coefficient of these blood parameters is not high enough to display a large magnitude of the effect, especially for total cholesterol, LDL and HDL, whose percentages of intra-individual biological variability do not exceed 9\% [51]. The concentrations of blood triglycerides may be less stable and more easily affected by recent meals, this being the reason that $12 \mathrm{~h}$ of fasting were required before the blood sample was drawn [51, 52].

Table 3 Controlled direct effect (CDE) of education in 2000 on blood lipid levels in 2010 when income change is set to "increased"

\begin{tabular}{|c|c|c|c|c|c|c|}
\hline \multirow[t]{2}{*}{ Variables In 2010} & \multicolumn{3}{|c|}{$\begin{array}{l}\text { Crude Model } \\
\text { CDE (95\% Cl) }\end{array}$} & \multicolumn{3}{|c|}{$\begin{array}{c}\text { Adjusted and weighted model }{ }^{a} \\
\text { CDE }(95 \% \mathrm{Cl})\end{array}$} \\
\hline & Total & Women & Men & Total & Women & Men \\
\hline Triglycerides (mg/dL) & $11(-6 ; 30)$ & $18(-1 ; 39)$ & $2(-34 ; 40)$ & $9(-11 ; 28)$ & $14(-7 ; 34)$ & $-2(-41 ; 38)$ \\
\hline Total cholesterol (mg/dL) & $-2(-10 ; 7)$ & $3(-7 ; 14)$ & $-12(-25 ; 2)$ & $-3(-12 ; 7)$ & $4(-8 ; 15)$ & $-12(-29 ; 5)$ \\
\hline LDL cholesterol (mg/dL) & $-4(-10 ; 3)$ & $1(-7 ; 9)$ & $-13(-23 ;-3)$ & $-4(-11 ; 3)$ & $1(-8 ; 9)$ & $-12(-24 ; 1)$ \\
\hline HDL cholesterol (mg/dL) & $-2(-5 ; 0)$ & $-4(-7 ;-1)$ & $1(-4 ; 6)$ & $-2(-5 ; 1)$ & $-3(-7 ; 0)$ & $1(-5 ; 6)$ \\
\hline
\end{tabular}

${ }^{a}$ Models adjusted for sex, age, birth weight, income at baseline, maternal education and family history of dyslipidemia 
It is important to mention that this is one of the first studies using a cohort study that investigates the effect of education on blood lipid levels in adults aged 35 years, considering an improvement in income over the past decade, using a mediation analysis that included exposure-mediator interaction and considering the technique of "inverse probability weighting" to correct for selection bias.

Another point to note is that according to the records of the Demography of the National Institute of Statistics of Chile, births at Limache Hospital who formed the sampling frame of this study accounted for $99 \%$ of live births in the communes of Limache and Olmué between 1974 and 1978. Furthermore, the quantification of blood lipid levels was performed in an internationally certified laboratory, in order to reduce analytical variability and ensure the delivery of accurate measurements and accurate blood parameters values.

Among the weaknesses of this study is the difficulty of measuring the mediator: "per-capita income", because generally people tend to overestimate or underestimate family income depending on the context in which the interview is conducted [53]. To minimize this information bias, we worked with trained professionals and supervised who applied the socioeconomic survey at the home of each participant and spent all the time needed to collect and accurately as possible socioeconomic information in the most complete way. Also, while we used inverse probability weighting to correct for selection bias with regard to observed variables, if those lost to followup were different with regard to unmeasured variables, some selection bias may remain.

For future research, it would be interesting to continue to follow participants over time to assess whether the effects change with age. The cohort could also be opened to other communities thereby increasing heterogeneity and sample size. In turn, studying the effect of characteristics at birth on blood lipid levels in adulthood would complement the results and would provide relevant information, since literature has raised the need for cohort studies with sufficient power and statistical data to generate robust and conclusive evidence in this area $[54,55]$.

\section{Conclusion}

This study found a qualitative interaction by sex in the effect of education on blood lipid levels when income increased over a decade: low education was associated with worse lipid profiles in women and with better lipid profiles in men. This information could help to better understand the pathways involved in the generation of this kind of socioeconomic inequalities. It also suggests that public health policy in Chile or Latin America that aims to reduce and/or control blood lipid levels in adults should consider men and women differently in order to be more effective.

\section{Abbreviations}

BL: Blood lipid levels; BMI: Body mass index; CDE: Controlled direct effect; Cl: 95\% confidence interval; HDL: HDL cholesterol; IPAQ: International Physical Activity Questionnaire; LDL: LDL cholesterol; TC: Total cholesterol; TG: Triglycerides

\section{Acknowledgements}

We are indebted to Dr. Jay kaufman (Department of Epidemiology, Biostatistics, and Occupational Health, McGill University, Canada) and Dr. Aluísio Barros (Centre of Epidemiological Research, Federal University of Pelotas, Brazil) for their statistical help.

\section{Funding}

This study was funded by the Wellcome Trust [ $N^{\circ}$ 05944827]; the Chilean National Fund for Scientific and Technological Development [N 1010572, N ${ }^{\circ}$

1100414]; and the Chilean National Commission for Scientific and

Technological Research [N² 21110244]. The funders played no role in the development of the research question, analysis or results of this study.

\section{Availability of data and materials}

The datasets analyzed during the current study are not publicly available due them containing information that could compromise research participant privacy/ consent but are available from the corresponding author on reasonable request.

\section{Authors' contributions}

ML proposed the aim of the study, the analytical approach, participated in data collection, carried out the analysis and drafted the manuscript. HA was in charge of the planning of the Limache project and reviewed the manuscript. All authors read and approved the final manuscript.

\section{Ethics approval and consent to participate}

This study was approved by the Ethics Committee at the University of Chile which abides by the Declaration of Helsinki principles. Participation was voluntary and all individuals signed an informed consent form to participate.

\section{Consent for publication}

Not applicable.

\section{Competing interests}

The authors declare that they have no competing interests.

\section{Publisher's Note}

Springer Nature remains neutral with regard to jurisdictional claims in published maps and institutional affiliations.

Received: 12 November 2017 Accepted: 19 February 2018

Published online: 27 February 2018

\section{References}

1. Global Health Observatory. Ten leading causes of death, 2015. Geneva: World Health Organization; 2015. http://www.who.int/mediacentre/ factsheets/fs310/en/. Accessed 01 Mar 2017

2. Mendis S, Puska P, Norrving B, editors. Global atlas on cardiovascular disease prevention and control. Geneva: World Health Organization; 2011. http:// whqlibdoc.who.int/publications/2011/9789241564373_eng.pdf. Accessed 01 Mar 2017

3. Department of Statistics and Health Information. Birth and mortality statistics in Chile, 2014. Santiago: Ministry of Health; 2016. http://www.deis. cl/wp-content/uploads/2016/12/Anuario-2014_publicable-fe-erratas-final-24. 10.2016.xlsx. Accessed 30 May 2017

4. Mathers C, Loncar D. Projections of global mortality and burden of disease from 2002 to 2030. PLoS Med. 2006;3(11):e442. https://doi.org/10.1371/ journal.pmed.0030442.

5. Escobar M, Obreque A. Implementation of risk-focus in the cardiovascular health program. Santiago: Ministry of Health; 2009. http:// buenaspracticasaps.cl/wp-content/uploads/2014/07/MINSAL-2009-enfoqueriesgo-CV.pdf. Accessed 02 Mar 2017

6. Alwan A. Global status report on noncommunicable diseases 2010. Geneva: World Health Organization; 2011. http://www.who.int/nmh/publications/ ncd_report_full_en.pdf. Accessed 03 Mar 2017 
7. Ministry of Health. National Health Survey ENS Chile 2009-2010. Santiago; 2010. http://web.minsal.cl/portal/url/item/ bcb03d7bc28b64dfe040010165012d23.pdf. Accessed 03 Mar 2017

8. Organisation for Economic Co-operation and Development. Enhancing Socia Inclusion in Latin America: Key Issues and the Role of Social Protection Systems. 2017. http://www.oecd.org/latin-america/regionalprogramme/ Enhancing-Social-Inclusion-LAC.pdf. Accessed 23 Dec 2017.

9. Ministry of Planning. National Socioeconomic Characterization Survey CASEN Chile 2009. Santiago; 2009. http://www.superacionpobreza.cl/wpcontent/uploads/2014/01/resultados_casen_2009.pdf. Accessed 06 Mar 2017

10. The World Bank. Overview: the World Bank in Chile. Santiago; 2017. http:/ www.worldbank.org/en/country/chile/overview. Accessed 28 Dec 2017

11. Organisation for Economic Co-operation and Development. OECD economic surveys: Chile 2010. Santiago; 2010. http://www.keepeek.com/ Digital-Asset-Management/oecd/economics/oecd-economic-surveys-chile2010_eco_surveys-chl-2010-en. Accessed 05 Mar 2017

12. Ministry of Health. [National health survey ENS Chile 2003] Santiago; 2004. http:// www.medicinadefamiliares.c//Protocolos/encnacsalres.pdf. Accessed 06 Mar 2017.

13. Pradeepa R, Prabhakaran D, Mohan V. Emerging economies and diabetes and cardiovascular disease. Diabetes Technol Ther. 2012;14(Suppl 1):S59-67. https://doi.org/10.1089/dia.2012.0065.

14. The Chilean National Institute for Sports. [National Survey of Physical Activity and Sports in the population over 18 years] Santiago; 2016. http:// www.mindep.cl/wp-content/uploads/2016/07/Informe-Ejecutivo-Final.pdf. Accessed 20 Dec 2017.

15. Ministry of Health, University of Chile. [National Food Consumption Survey ENCA Chile 2010-2011 Final Report] Santiago; 2015. http://web.minsal.cl/ sites/default/files/ENCA-INFORME_FINAL.pdf. Accessed 28 Mar 2017.

16. Pampel FC, Krueger PM, Denney JT. Socioeconomic disparities in health behaviors. Annu Rev Sociol. 2010;36:349-70. https://doi.org/10.1146/ annurev.soc.012809.102529.

17. Egerter S, Braveman P, Sadegh-Nobari T, Grossman-Kahn R, Dekker M. Issue brief \#5-education and health. San Francisco: Robert Wood Johnson Foundation; 2011. http://www.rwjf.org/content/dam/farm/reports/issue_ briefs/2011/rwjf70447. Accessed 27 Mar 2017

18. Cutler DM, Lleras-Muney A. Understanding differences in health behaviors by education. J Health Econ. 2010;29(1):1-28. https://doi.org/10.1016/j. jhealeco.2009.10.003.

19. Li J, Powdthavee N. Does more education lead to better health habits? Evidence from the school reforms in Australia. Soc Sci Med. 2015;127:83-91. https://doi.org/10.1016/j.socscimed.2014.07.021.

20. Blanck HM, Gillespie C, Kimmons JE, Seymour JD, Serdula MK. Trends in fruit and vegetable consumption among U.S. men and women, 1994-2005. Prev Chronic Dis. 2008:5(2):A35. PMID: 18341771

21. Harper S, Lynch J. Trends in socioeconomic inequalities in adult health behaviors among U.S. states, 1990-2004. Public Health Rep. 2007;122(2):17789. https://doi.org/10.1177/003335490712200207.

22. World Health Organization. Social Determinants of Health - The Solid Facts. 2nd ed. Marmot M, Wilkinson R, editors. Denmark: WHO Regional Office for Europe; 2003.

23. Diez Roux AV, Mair C. Neighborhoods and health. Ann N Y Acad Sci. 2010; 1186:125-45. https://doi.org/10.1111/j.1749-6632.2009.05333.x.

24. Teixeira PJ, Carraça EV, Marques MM, Rutter H, Oppert JM, De Bourdeaudhuij l, et al. Successful behavior change in obesity interventions in adults: a systematic review of self-regulation mediators. BMC Med. 2015; 13(1):84. https://doi.org/10.1186/s12916-015-0323-6.

25. Senn TE, Walsh JL, Carey MP. The mediating roles of perceived stress and health behaviors in the relation between objective, subjective, and neighborhood socioeconomic status and perceived health. Ann Behav Med. 2014;48(2):215-24. https://doi.org/10.1007/s12160-014-9591-1.

26. Cohen S. Social relationships and health. Am Psychol. 2004;59(8):676-84. https://doi.org/10.1037/0003-066X.59.8.676.

27. Amigo H, Bustos $P$, Zumelzú E, Rona RJ. Cohort profile: the Limache, Chile, birth cohort study. Int J Epidemiol. 2014;43(4):1031-9. https://doi.org/10. 1093/ije/dyt091.

28. Organisation for Economic Co-operation and Development. OECD framework for statistics on the distribution of household income, consumption and wealth. Paris: OECD Publishing; 2013. http://www.oecd.org/statistics/ framework-for-statistics-on-the-distribution-of-household-incomeconsumption-and-wealth-9789264194830-en.htm. Accessed 01 Apr 2017
29. Organisation for Economic Co-operation and Development. Dataset: Consumer prices (MEI) reported by the National Statistics Institute of Chile. Paris; 2014. http://stats.oecd.org/Index.aspx?DatasetCode=MEI_FIN\#. Accessed 20 Mar 2017

30. Adimark. [The Esomar Socioeconomic Level: Application Manual] Santiago; 2000. http://www.microweb.cl/idm/documentos/ESOMAR.pdf. Accessed 22 Mar 2017

31. World Health Organization. Physical status: the use and interpretation of anthropometry. Geneva; 1995. http://apps.who.int/iris/bitstream/10665/ 37003/1/WHO_TRS_854.pdf. Accessed 23 Mar 2017.

32. The International Physical Activity Questionnaire Group. Guidelines for Data Processing and Analysis of the International Physical Activity Questionnaire (IPAQ). 2005. https://sites.google.com/site/theipaq/scoring-protocol. Accessed 23 Mar 2017

33. Friedewald WT, Levy RI, Fredrickson DS. Estimation of the concentration of low-density lipoprotein cholesterol in plasma, without use of the preparative ultracentrifuge. Clin Chem. 1972;18(6):499-502. PMID: 4337382

34. Valeri L, Vanderweele TJ. Mediation analysis allowing for exposure-mediator interactions and causal interpretation: theoretical assumptions and implementation with SAS and SPSS macros. Psychol Methods. 2013;18(2): 137-50. https://doi.org/10.1037/a0031034.

35. Hernan MA, Hernandez-Diaz S, Robins JM. A structural approach to selection bias. Epidemiology. 2004;15(5):615-25. https://doi.org/10.1097/01. ede.0000135174.63482.43.

36. Seaman SR, White IR. Review of inverse probability weighting for dealing with missing data. Stat Methods Med Res. 2013;22(3):278-95. https://doi. org/10.1177/0962280210395740.

37. Ministry of Social Development. [National Socioeconomic Characterization Survey CASEN Chile 2000: database] Santiago; 2000. http://observatorio. ministeriodesarrollosocial.gob.c//layout/doc/bases/Casen2000.rar. Accessed 16 Apr 2017.

38. Ministry of Social Development. [National Socioeconomic Characterization Survey CASEN Chile 2009: database] Santiago; 2009. http://observatorio. ministeriodesarrollosocial.gob.cl/layout/doc/bases/Casen2009spss.rar. Accessed 16 Apr 2017.

39. Ministry of Health.[National Health Survey ENS Chile 2009-2010: database] Santiago; 2012. http://epi.minsal.cl/wp-content/uploads/2016/03/ENS-20092010-DEPTO.EPIDEMIOLOGIA-MINSAL-SPSS-Version.rar. Accessed 30 May 2017.

40. Kim SH, Reaven G. Sex differences in insulin resistance and cardiovascular disease risk. J Clin Endocrinol Metab. 2013;98(11):E1716-21. https://doi.org/ 10.1210/jc.2013-1166.

41. Sandberg K, Ji H. Sex differences in primary hypertension. Biol Sex Differ. 2012;3:7. https://doi.org/10.1186/2042-6410-3-7.

42. Swinburn BA, Sacks G, Hall KD, McPherson K, Finegood DT, Moodie ML, et al. The global obesity pandemic: shaped by global drivers and local environments. Lancet. 2011;378(9793):804-14. https://doi.org/10.1016/S01406736(11)60813-1.

43. Williams L, Andrianopoulos N, Cleland V, Crawford D, Ball K. Associations between education and personal income with body mass index among Australian women residing in disadvantaged neighborhoods. Am J Health Promot. 2013;28(1):59-65. https://doi.org/10.4278/ajhp.120316-QUAN-143.

44. Gigante DP, Dias-da-Costa JS, Olinto MT, Menezes AM, Silvia M. Adult obesity in Pelotas, Rio Grande do Sul, Brazil, and the association with socioeconomic status. Cad Saude Publica. 2006;22(9):1873-9. https://doi.org/ 10.1590/S0102-311X2006000900018.

45. Morales M, Méndez I, Shamah T, Valderrama Z, Melgar H. Food insecurity is associated with obesity in adult women of Mexico. Salud Publica Mex. 2014; 56(Suppl 1):S54-61. PMID: 25649454

46. Monteiro C, Conde W, Popkin B. Independent effects of income and education on the risk of obesity in the Brazilian adult population. J Nutr. 2001;131(3):881S-6S. PMID: 11238779

47. Ministry of Health, University of Chile. [National Food Consumption Survey ENCA Chile 2010-2011: database] Santiago; 2015. http://web.minsal.cl/sites/ default/files/files/ENCA_Er24h_Nutrientes_AJUSTADO.sav. Accessed 31 May 2017.

48. Olafsdottir AS, Thorsdottir I, Gunnarsdottir I, Thorgeirsdottir H, Steingrimsdottir L. Comparison of women's diet assessed by FFQs and 24hour recalls with and without underreporters: associations with biomarkers. Ann Nutr Metab. 2006;50(5):450-60. https://doi.org/10.1159/000094781. 
49. Scagliusi FB, Ferriolli E, Pfrimer K, Laureano C, Cunha CS, Gualano B, et al. Characteristics of women who frequently under report their energy intake: a doubly labelled water study. Eur J Clin Nutr. 2009;63(10):1192-9. https:// doi.org/10.1038/ejcn.2009.54

50. Briñol P, Falces C, Becerra A. Attitudes. In: Morales JF, Huici C, Moya M, Gaviria E, editors. [social psychology] 3rd ed. Madrid: McGraw-Hill; 2007. p. 457-90.

51. Guzman AM. When two consecutive laboratory results indicate a change in health status in a patient? Rev Med Chil. 2010;138(6):780-3. PMID: 20919491

52. Ministry of Health. [Technical Standards: Dyslipidemias] Santiago; 2000. http://web.minsal.cl/portal/url/item/75fefc3f8128c9dde04001011f0178d6.pdf. Accessed 24 May 2017

53. Galobardes B, Shaw M, Lawlor DA, Lynch J, Smith GD. Indicators of socioeconomic position (part 1). J Epidemiol Community Health. 2006;60(1): 7-12. https://doi.org/10.1136/jech.2004.023531.

54. Laurén L, Järvelin MR, Elliott P, Sovio U, Spellman A, McCarthy M, et al. Relationship between birthweight and blood lipid concentrations in later life: evidence from the existing literature. Int J Epidemiol. 2003;32(5):862-76. https://doi.org/10.1093/ije/dyg201.

55. Nair H, Shu XO, Volmink J, Romieu I, Spiegelman D. Cohort studies around the world: methodologies, research questions and integration to address the emerging global epidemic of chronic diseases. Public Health. 2012; 126(3):202-5. https://doi.org/10.1016/j.puhe.2011.12.013.

Submit your next manuscript to BioMed Central and we will help you at every step:

- We accept pre-submission inquiries

- Our selector tool helps you to find the most relevant journal

- We provide round the clock customer support

- Convenient online submission

- Thorough peer review

- Inclusion in PubMed and all major indexing services

- Maximum visibility for your research

Submit your manuscript at www.biomedcentral.com/submit
Biomed Central 